University of Chicago Law School

Chicago Unbound

Journal Articles

Faculty Scholarship

1969

\title{
The Constitution and the Tenure of Federal Judges: Some Notes from History
}

Philip B. Kurland

Follow this and additional works at: https://chicagounbound.uchicago.edu/journal_articles

Part of the Law Commons

\section{Recommended Citation}

Philip B. Kurland, "The Constitution and the Tenure of Federal Judges: Some Notes from History," 36 University of Chicago Law Review 665 (1969).

This Article is brought to you for free and open access by the Faculty Scholarship at Chicago Unbound. It has been accepted for inclusion in Journal Articles by an authorized administrator of Chicago Unbound. For more information, please contact unbound@law.uchicago.edu. 


\title{
The Constitution and the Tenure of Federal Judges: Some Notes from History
}

\author{
Philip B. Kurland $\dagger$
}

\begin{abstract}
Almost every generation since the founding of this nation has raised the question, in one form or another, for good reasons and bad, whether federal judges are removable from their offices by means other than impeachment and for causes other than the commission of "high crimes or misdemeanors." The issue has never been successfully framed for a definitive resolution by the Supreme Court. Those who would bestow a monopoly of constitutional construction on the Court have, therefore, to face the problem without adequate judicial authority on which to rest argument. Nor have the other branches of the national government, equally sworn to uphold the Constitution, afforded a clear answer to the problem.

The materials collected in this article, largely from non-judicial sources, are offered with the thought that a few pages of history may be worth a Supreme Court dictum. For the issue has once again been raised in the Senate. This time the objective of the legislators appears to be benign. It does not derive from the conflicts engendered by an unpopular judiciary. The bill introduced in the first session of the 91st Congress ${ }^{1}$ had its origins in a bill offered in the 90th Congress and
\end{abstract}

† Professor of Law, The University of Chicago.

I S. 1506, 91st Cong., 1st Sess. (1969), may be taken as typical of several bills directed toward the same end. It was introduced on March 12, 1969. Its provisions relevant to the immediate inquiry are summarized by the Legislative Reference Service in this way:

Judicial Reform Act-Title I: Commission on Judicial Disabilities and TenureEstablishes within the judicial branch of the Government a Commission on Judicial Disabilities and Tenure composed of five members. Requires each member be a judge of the United States who is in regular active service. Requires the Commission, at all times, to include at least two district judges, and two circuit judges. Provides that all members be assigned to the Commission by the Chief Justice of the Supreme Court. Makes the term of the Commission four years.

Provides that the Commission shall promote the honorable and efficient administration of justice in the courts of the United States. Permits it to act to retire or remove a judge only after an investigation and formal hearing in accordance with the requirements of due process. Provides that a decision to remove a judge for misconduct shall be subject to review by the Judicial Conference and ultimately by the Supreme Court by certiorari. Makes such proceedings confidential.

Enables the Commission to undertake an investigation of a judges [sic] physical or mental fitness upon a report of any person. Gives the Commission necessary powers such as the subpoena power, depositions, etc. Authorizes the payment of fees and mileage of witnesses and provides that U.S. marshals shall serve 
in no way is it attributable to the successful foray against Mr. Justice Fortas. Nevertheless the infamous Fortas affair may well contribute to its enactment, despite the fact that the bill does not affect Supreme Court Justices. Senator Tydings, the prime sponsor of the bill, has been patently concerned only with the worthy objective of improvement of the machinery for the administration of justice. His concern is with the process not the substance of judicial litigation. His concern is about the senile, the inebriate, and the corrupt judge rather than those who have simply rendered decisions that have offended the sensitivities of executive and legislative officials. But it should be kept in mind that tools created by the well-intentioned for beneficent uses may fall into less worthy hands to be used for less appropriate ends. If the Supreme Court is not directly touched by this proposed legislation, use and legitimation of this legislation will afford ample precedent for similar treatment of Supreme Court Justices. When dealing with so fundamental and so fragile a notion as the independence of the judiciary, one ough $\bar{h}$ to tread warily lest the ultimate cost far outweigh the immediate gains.

In any event, the defects of our national judiciary are not, to my mind, attributable primarily to the faults of the removal process. For every inebriate, senile, and malfeasant judge on the federal bench, there are several dullards and sluggards immune from removal whatever new standards and machinery are offered. The essential problem is to be found in the process that has made federal judicial appointments prime patronage plums to be awarded by Senators in acknowledgement of party or personal loyalty. (At the highest level, the patronage is the personal prerogative of the President.) As Mr. Justice Frankfurter once noted in another context:" "Fit legislation and fair adjudication are attainable. The ultimate reliance of society for the proper fulfillment of both these august functions is to entrust them only to those who are equal to their demands."

This is not to suggest that legislative alternatives to the appointment process should be sought. It should be clear by now that differences in the machinery for judicial selection have made little or no difference in the quality of the judiciary. Certainly the politics of the bar associations offer no advantages over the politics of our elected officials. A combination of the two is likely to provide only exacerba-

process and execute orders for the Commission.

Digest of Public General Bills and Resolutions, 91st Cong., 1st Sess,, Legis. REF. SERv. A-97 (1969).

There are obvious constitutional problems in addition to the one treated in the text, including the problem of a case or controversy, right to jury trial, etc.

2 F. Frankfurter, Some Reflections on the Reading of Statutes 29 (1947). 
tion of the faults of each. The basic difficulty is to secure recognition of the necessity for merit appointments. How this sense of responsibility is to be secured is a question that has not yet been answered. Nor is it realistic to expect such improvement at a time when equality rather than quality is the watchword of government; when mediocrity rather than talent recommends men for appointment to high posts. But certainly there is no point in tinkering with the independence of federal judges by subjecting their tenure to control of other federal judges appointed by the same defective process. Without their independence, the federal judges will have lost all that separates them from total subordination to the political processes from which they ought to be aloof.

In the event that my bias is not yet clear, I would say that I am in wholehearted agreement with Mr. Justice Black's opinion in Chandler v. Judicial Council of the Tenth Circuit of the United States, ${ }^{3}$ where he dealt with the problem that neither the Court nor the Congress has been prepared to face squarely:

One of the great advances made in the structure of government by our Constitution was its provision for an independent judiciary-for judges who could do their duty as they saw it without having to account to superior court judges or to anyone else except the Senate sitting as a court of impeachment. Article II, $\S 4$, of the Constitution provides that "Officers of the United States," which includes judges, "shall be removed from Office on Impeachment for, and Conviction of, Treason, Bribery, or other High Crimes and Misdemeanors," and Art. I, $\$ \S 2$ and 3, state that impeachment can be instituted only on recommendation of the House of Representatives and that trial can be held only by the Senate. To hold that judges can do what this Judicial Council has tried to do to Judge Chandler here would in my judgment violate the plan of our Constitution to preserve, as far as possible, the liberty of the people by guaranteeing that they have judges wholly independent of the Government or any of its agents with the exception of the United States Congress acting under its limited power of impeachment. We should stop in its infancy, before it has any growth at all, this idea that United States district judges can be made accountable for their efficiency or lack of it to judges just over them in the federal system. . . .

Nor am I impressed by the recent vogue among the States to provide

8382 U.S. 1003, 1005 (1966). The case, after a mysterious disappearance, has now reappeared on the Court's docket for the 1969 Term. 
means for chastising judges who get out of line. Admittedly, the worse the quality the more external restraint that is required, provided that the rein is in proper hands. But the various devices that the States have recently adopted for policing their judiciaries are little more than polite blackmail, suggestions that the bar is unhappy with the judge's behavior and he'd better shape up or else. I shudder to think how early the federal courts might have been deprived of the services of Judge Learned Hand under such a system as California's. For politeness to counsel and a willingness to tolerate fools gladly were not among his virtues, and it is only such virtues and that of regular attendance at the court house that the policing systems seem capable of evoking from timid judges.

On the question of judicial removal, much has been written. There is more literature than learning. If the issue is deemed to be resoluble by the intention of the Founding Fathers, I think that it has been made pellucidly clear by Martha Ziskind that the intention was to make impeachment the sole means of removal of federal judicial officers. ${ }^{4}$ I do not, therefore, propose to reexamine the problem of original intention here. I propose, here, to look at post-adoption history to see how the three branches of the national government have dealt with the problem in the past. I have not exhausted these materials but only sampled them. But, as with most social scientists, my sample is adequate to reveal support for my hypothesis, that legislation providing alternative means of removal is not the appropriate response to such problems of judicial tenure as may exist.

\section{Judiclal Atritude}

The absence of a definitive answer from the Court on the question whether a federal judge of a constitutional court might be removed by some process other than impeachment is due to the failure to present the issue for judicial resolution. It could come to the Court only after the executive, the legislature, or the judiciary attempted to effect such removal. With two exceptions, none of these branches of the government has seen fit to force the question. The first exception relates to the repeal of the Judiciary Act of 1801, which destroyed several judgeships created by the previous administration. ${ }^{5}$ The repealing statute was never the subject of challenge in the courts. The second exception might be found in the case of removal-de facto if not de jure-of District Judge Chandler by the Tenth Judicial Cir-

4 Ziskind, Judicial Tenure in the American Constitution: English and American Precedents. This article will appear in 1969 SUP. Cr. REv. -

5 See text at notes 12-26 infra. 
cuit. ${ }^{6}$ Aside from the .Black opinion quoted above, the Court said nothing about the issues raised by this action.

As is often the case, however, on many occasions when the issue was not the subject of Supreme Court resolution, it was the subject of Supreme Court dictum. These dicta are consistent in their construction of the Constitution as requiring life tenure not subject to abbreviation except by the terms of the Constitution. Starting with Marshall's proposition in American Insurance Co. $v$. Canter, ${ }^{7}$ through the extensive discussion in a multitude of opinions in Glidden Co. $v$. Zdanok, ${ }^{8}$ the line has been consistent with the authority cited by $\mathrm{Mr}$. Justice Douglas in the latter case: Alexander Hamilton. The quotation from Hamilton included the following: ${ }^{9}$

The precautions for their responsibility are comprised in the article respecting impeachments. They are liable to be impeached for malconduct by the House of Representatives, and tried by the Senate; and, if convicted, may be dismissed from office, and disqualified for holding any other. This is the only provision on the point which is consistent with the necessary independence of the judicial character, and is the only one which we find in our own Constitution in respect to our own judges.

Indeed, as Glidden makes clear, whichever of the opinions is read, the essential hallmark of a constitutional court is life tenure guaranteed by the Constitution.

It should be pointed out, however, that just as several members of the judiciary have in the past recommended a retirement age for federal judges, so too have some commended the notion of a removal process short of impeachment. In each case, however, the judicial commentator made it clear that his recommendation did not include an opinion that such removal process would satisfy the demands of the Constitution. Mr. Justice Jackson appeared before a Senate Committee in 1941, shortly after his appointment to the Court, to endorse the need for a more sophisticated and less cumbersome process for removal than by impeachment. He was careful to preface his position

\footnotetext{
6 See note 3 supra.

726 U.S. (1 Pet.) 511, 546 (1828).

8370 U.S. 530 (1962). Additional cases in this line include: Ex parte Bakelite, 279 U.S. 438, 449 (1928); Downes v. Bidwell, 182 U.S. 244, 266 (1900); United States v. Guthrie, 58 U.S. (17 How.) 284, 309 (1854) (dissenting opinion); see also argument by Attorney General Cushing in that case, 58 U.S. (17 How.) at 285-6; Ex parte Hennen, 38 U.S. (13 Pet.) 225, 258-9 (1839).

9 The FEDERAlist No. 79, at 491-3 (H. Lodge ed. 1908) (A. Hamilton), quoted in 370 U.S. at 595 .
} 
thus: "There are two aspects of the matter that I do not want to discuss. One is the issue of constitutionality, as to which I take the position that the judicial conference under Ghief Justice Hughes and under Chief Justice Stone has taken in discussing the policy of the matter without expressing any opinion on constitutionality."10

The position of the Judicial Conference, which Jackson referred to, was also one of support for the plan, if it were constitutional.11 The fate of the legislation which evoked these statements from judicial officers was defeat in Congress, with extensive arguments made as to the unconstitutional nature of the legislation, the question on which the judges had abstained.

\section{Congressional Views}

The problem of judicial tenure and removal has been the subject of congressional concern far more often than it has been the object of judicial scrutiny. Appropriate analysis of the constitutional conventions as understood by Congress would require an exhaustion of the debates and bills and committee reports. (As I already indicated, except for the repeal of the Judiciary Act of 1801, there has been no legislation directly on the subject.) I have attempted here to extract a few samples chosen on a very unscientific basis. I have looked only to a few of the critical periods when judicial-legislative conflict was most aggravated. A study of calmer times may reveal more considered understanding. But it is in times of stress that constitutional conditions are likely to be reshaped to meet new needs.

\section{A. Repeal of the Judiciary Act of 1801}

To begin at the beginning requires a look at the famous debates over the repeal of the Judiciary Act of $1801 .{ }^{12}$ Certainly this was one of the most hotly contested political controversies that wracked the young Republic. The background of the 1801 statute makes the controversy more easily understood:13

\footnotetext{
10 Hearings Before a Subcomm. of the Comm. on the Judiciary of the United States Senate on H.R. 146, 77th Cong., 1st Sess. 25 (1941).

11 The attitude of the Judicial Conference was reported this way:

A committee consisting of Judges Biggs, Phillips, and Learned Hand considered the advisibility of legislation with respect to an alternative for impeachment proceedings in the case of circuit and district judges charged with derelictions. On the report of the committee the Conference adopted the following resolution: "Assuming its constitutionality, as to which we express no opinion, we are in accord with the general purpose and approve in principle the provisions embodied in H.R. 9160, Seventy-sixth Congress, third session."

1940 ATT'y GEN. ANN. REP. 32.

12 Act of Feb. 13, 1801, ch. 4, 2 Stat. 89 (1801).

13 F. Frankfurter \& J. Landis, Business of the Supreme Court 20-21, 23-25 (1927) (footnotes in original omitted).
} 
In fact, the Justices carried out the hopes that were entertained for them as inculcators of national patriotism. They utilized charges to the grand juries as opportunities for popular education. ${ }^{14}$ Jay, Cushing, Wilson, Iredell, all indulged in the practice. These "elegant" and "eloquent" speeches received wide publicity. Having a Federalist flavor with more or less pungency, they promptly aroused political opposition. That the Circuit Justices helped to further the Federalist cause there can hardly be doubt. That they helped to consolidate the opposition is no less clear. Criticism against the Judiciary was accumulating from friends, as well as enemies, of a strong federal bench. Ardent Federalists with increasing vigor urged Randolph's proposal for separate circuit judges; the emerging Jeffersonian Party came to regard the federal courts as a political adjunct of the hated Federalists. The judicial system was drawn into the vortex of politics.

-...

Dissatisfaction with the existing system was also fed by the desire of influential opinion to extend the scope of federal jurisdiction. The interference of local prejudices with the enforcement of federal law stimulated the proponents of a more comprehensive federal judiciary. But no serious attempt looking towards drastic reform appears until John Adams, in 1799, brought the matter before Congress. His recommendation culminated in the notorious Act of February 13,1801 . This measure combined a thoughtful concern for the federal judiciary with selfish concern for the Federalist party.

With the election of the Jeffersonians, the 1801 Act was doomed. But the question remained as to the proper means for reducing the statute that the Federalists had enacted from such partisan motives. The battle included not only the contest over the Judiciary Act, but the question of the propriety of judicial review as fostered by Marbury $v$. Madison, ${ }^{15}$ and the failure of the impeachment proceedings against $\mathrm{Mr}$. Justice Chase.

For our purposes, the interesting parts of the debates were concerned not with the power of judicial review which was also subject to attack, but with the propriety of abolishing the newly created judgeships, thus ending the tenure of the newly appointed judges. When the First Judiciary Act was being considered, Mr. Smith of South Carolina had admonished care in its preparation. For, he said, "The judges are

14 See Lerner, The Supreme Court as Republican Schoolmaster, 1967 SUp. CT. REv. 127.

155 U.S. (1 Granch) 137 (1803). 
to hold their commissions during good behaviour, and after they are appointed, they are only removable by impeachment; consequently this system must be a permanent one."16 $\mathrm{He}$ obviously underestimated the imaginative capacities of his successors.

Senator Breckenridge of Kentucky had sought the advice of John Taylor of Caroline in order to mount an attack on the Judiciary Act of 1801. The statute had, among other things, abolished two district courts in Kentucky and Tennessee, although retaining the judges in office by assigning them to the newly created circuit courts. Taylor's advice was found among the Breckenridge manuscripts and provided the basis for the action taken by Congress in abolishing the 1801 judgeships: ${ }^{17}$

Congress are empowered from time to time to ordain and establish inferior courts.

The law for establishing the present inferior courts is a legislative instruction affirming that, under this clause, Congress may abolish as well as create these judicial offices, because it does expressly abolish the then existing courts for the purpose of making way for the present.

It is probable that this construction is correct, but it is equally pertinent to our object whether it is or not. If it is, then the present inferior courts may be abolished as constitutionally as the last; if it is not, then the law for abolishing the former and establishing the present was unconstitutional, and being so, is undoubtedly repealable.

Thus the only ground which the present inferior courts can take is that Congress may from time to time create, regulate, or abolish such courts as the public interest may dictate, because such is the very tenure under which they exist.

... The Constitution declares that the judge shall hold his office during good behavior. Could it mean that he should hold this office after it was abolished? Could it mean that his tenure should be limited by behaving well in an office which did not exist? It must either have intended these absurdities or admit of a construction which will avoid them. This construction obviously is that an officer should hold that which he might hold, namely an existing office, so long as he did that which he might do, namely his duty in that office; and not that he should hold an office which did not exist or perform duties not sanctioned by law. If, therefore,

16 I ANNALS of Cong. 828 (1789).

17 Breckenridge MSS., Nov. 21, 1801, quoted in Carpenter, Repeal of the Judiciary Act of 1801, 9 AM. PoL. Scr. REv. 519,523-6 (1915). 
Congress can abolish the courts, as they did by the last law, the officer dies with the office, unless you allow the Constitution to admit impossibilities as well as absurdities.

Nor is it incompatible with the "good behavior" tenure when its origin is considered. It was invented in England to counteract the influence of the crown over the judges. And we have rushed into the principle with such precipitancy, in imitation of this our general prototype, as to have outstript monarchists in our efforts to establish a judicial oligarchy; their judges being removable by a joint vote of Lords and Commons, and ours by no similar or easy process.

The tenure, however, is evidently bottomed on the idea of securing the honesty of judges while exercising the office, and not upon that of sustaining useless or pernicious offices for the sake of the judges. The regulation of offices in England, and indeed of inferior offices in most or all countries, depends upon the legislature; it is a part of the detail of government which necessarily devolves upon it, and is beyond the foresight of a constitution because it depends upon variable circumstances. And in England a regulation of the courts of justice was never supposed to be a violation of the good behavior tenure. If this principle should disable Congress from erecting tribunals which temporary circumstances might require, without entailing them upon the society after these circumstances by ceasing had converted them into grievances, it would be used in a mode contemplated neither in its original or duplicate.

Whether courts are erected by a regard to the administration of justice or with the purpose of rewarding a meritorious faction, the legislature may certainly abolish them without infringing the Constitution whenever they are not required by the administration of justice, or the merit of the faction is exploded and their claim to reward disallowed.

This was the exact line taken by Senator Breckenridge in the Senate debates, but not without argument.

It is, perhaps, not irrelevant to point out a distinction that was sought to be drawn between legislation affecting the lower federal courts and legislation concerning the Supreme Court, the former alleged to be creatures of Congress and the latter to be ordained by the Constitution. In the words of one of the Republicans, Stevens Thomson Mason:18

1811 Annals of Cong. 59 (1801). 
... I observe ... a clear distinction between the Supreme Court and the other courts. With regard to the institution of the Supreme Court the words of the Constitution are imperative; while with regard to the inferior courts they are discretionary. ... [T] he Legislature should have power, from time to time, to create, to annul, or to modify the courts as the public good might require, whenever a change of circumstances may suggest the propriety of a different organization.

Senator Stone spoke directly to the issue presented here: ${ }^{19}$

... They doubtless shall, (as against the President's power to retain them in office) in common with other office[r]s of his appointment, be removed from office by impeachment and conviction; but it does not follow that they might not be removed by other means. They shall hold their offices during good behaviour, and they shall be removed from office upon impeachment and conviction of treason, bribery, and other high crimes and misdemeanors. If the words, impeachment of high crimes and misdemeanors, be understood according to any construction of them hitherto received and established, it will be found, that although a judge, guilty of high crimes and misdemeanors, is always guilty of misbehaviour in office, yet that of the various species of misbehaviour in office, which may render it exceedingly improper that a judge shall continue in office, many of them are neither treason, nor bribery, nor can they be properly dignified by the appellation of high crimes and misdeameanors; and for the impeachment of which no precedent can be found; nor would the words of the Constitution justify such impeachment.

To what source, then, shall we resort for a knowledge of what constitutes this thing called misbehaviour in office? ... Their misbehaviour certainly is not an impeachable offence; still it is the ground upon which judges are to be removed from office. The process of impeachment, therefore, cannot be the only one by which the judges may be removed from office under, and according to the Constitution.

The additional removal power is in the legislature. Only the President is restricted on "removal." The powers given the legislature-to have the courts meet only every six or ten years, to pack the court, etc. -show that no significant barrier was intended as against the legislature's control of judges.

$19 \mathrm{Id}$. at 72. 
Senator Bradley also followed the Taylor line. The words "good behavior" have been given assorted meanings in assorted states, but the most appropriate meaning is that used at their source, England. In England, the putting down of courts and justices is considered consistent with holding office during good behavior.

In the House, Representative Giles, on behalf of repeal, asserted that the term independence of judges or of the judiciary department was not to be found in the Constituion but was a mere inference from some of the specified powers. The Constitution only declared that there should be such a department formed by the other two departments who owe a responsibility to the people. The only limitation upon the power of Congress consists in the number of supreme courts to be established, and the spirit, as well as the words of the Constitution, are completely satisfied provided one Supreme Court be established. He therefore felt the firmest conviction that there was no constitutional impediment in the way of repealing the act in question.

John Randolph sought a more sophisticated line and one that might be impossible to draw: ${ }^{20}$

I am free to declare that if the intent of this bill is to get rid of the judges, it is a perversion of your power to a base purpose; it is an unconstitutional act. If, on the contrary, it aims not at the displacing one set of men, from whom you differ in political opinion, with a view to introducing others, but at the general good by abolishing useless offices, it is a Constitutional act.

Representative Williams asserted that power to decide what grounds are constitutionally adequate for impeachment must be in the legislature. Otherwise the judge can rule any attempt to oust him to be unconstitutional. Courts were created in the interest of the people, not of the judges, and the representatives of the people must, therefore, have final control. It is enough that judges are free from diminution of salary. The characterization of a life contract is inapt.

The opponents of Breckenridge's propositions were not silent. Senator Tracy attempted to dispose of the distinction between the Supreme Court and lower federal courts: ${ }^{21}$ "No person will say that the judges of the Supreme Court can be removed, unless by impeachment and conviction of misbehaviour; but the judges of the inferior courts, as soon as ordained and established, are placed on precisely the same grounds of independence with the judges of the Supreme Court." 
Governeur Morris claimed that there was no power of removal except on impeachment:"22 "Misbehaviour is not a term known in our law; the idea is expressed by the word misdemeanor; which word is in the clause respecting impeachments. Taking, therefore, the two together . . the Constitution says: 'The judges shall hold their offices so long as they demean themselves well; but if they shall misdemean, if they shall on impeachment be convicted of misdemeanor, they shall be removed." "

Senator Mason also denied any way of removing a judge from office or the office from the judge except by way of impeachment.

Senator White proposed that on accepting their appointments judges entered into a contract with the government that guaranteed life tenure during good behavior, so that any law diminishing their tenure would be an unconstitutional impairment of contract and ex post facto law. Senator Chipman also asserted that continuance of office during good behavior was solely at the option of the judge. $\mathrm{He}$ relied in part on the proposition that the Constitution, having provided an exception to life tenure by way of the misbehavior clause, excluded all other bases for limiting tenure.

Senator Calhour asserted that once a judge received his commission, he was "completely beyond the reach of Legislative power. . . . We all fully and at once understand what is good behaviour in a judge, the oath he takes and the very nature of the office show it; to act with justice, integrity, ability, and honor, and to administer justice speedily and impartially, is good behaviour; if he acts contrary, it would be misbehaviour, and the Constitution, in that case, has given a remedy by impeachment." 23

Senator Ross rejected the notion that the standard was the same here as in Great Britain where the Crown on the address of both houses could limit tenure. He relied on the need for independence of the judiciary as described by Judge Pendleton of the high court of Virginia.

The judiciary had its defenders in the House of Representatives as well. Hemphill argued that the power to interfere with the judiciary was reserved to the people by the ninth and tenth amendments, in order to assure the people an independent judiciary. Bayard argued that if the judges had shown undue partisanship, the proper remedy was by way of impeachment: "What is meant by tenure of 'good behavior'?" It meant a tenure for life, unless the judge committed a misdemeanor. This was the understanding in England. The only ex-

22 Id. at 90.

23 Id. at $139-40$. 
press condition was the requirement of good behavior. The provision for such basis for removal precluded any other bases. The framers of the Constitution had been offered the opportunity to provide for removal of judges by other means and had rejected it.

Representative Smith asserted that while the legislature had the power to remove the jurisdiction of the lower courts it had no authority to limit the tenure of the judges except by impeachment. And Representative Rutledge turned to The Federalist for support of a similar conclusion. He quoted from No. 78:24

... good behaviour for the continuance in office of the judicial magistracy, is the most valuable of the modern improvements in the practice of government. . . . And it is the best expedient that can be devised in any Government to secure a steady, upright, and impartial administration of the laws. ... The complete independence of the courts of justice is essential in a limited Constitution; one containing specific exceptions to the legislative authority. . . . Such limitations can be preserved in practice no other way than through the courts of justice .... The Convention acted wisely in establishing good behaviour as the tenure of judicial offices. This plan would have been inexcusably defective had it wanted this important feature of good government.

He concluded from this that judges were removable only by impeachment. He then quoted from Madison's debates on the first judiciary bill: "The judges are to be removed only on impeachment, and conviction before Congress." ${ }^{25}$ And from Mr. Gerry:26 "The judges will be independent, and no power can remove them: they will be beyond the reach of the other porvers of the Government; they will be unassailable, and cannot be affected but by the united voice of America, and that only by a change of Government . . .," i.e., by constitutional amendment or revolution.

A most eloquent defense of judicial independence was made by Mr. Griswold. It was clear to him that judges could lose their office only on conviction for misbehavior after impeachment. He found that the failure to provide for the inclusion of the power of removal that was existent in England, i.e., on motion of both houses of Parliament and action taken pursuant thereto by the Crown, was deliberate.

Mr. Dana was even more persuasive. He, too, showed that the 
proposal for removal by joint motion of both houses was laid before the convention and rejected. Jefferson's Virginia constitution specifcally provided that judges of the higher court should hold tenure during good behavior but judges of the lower courts should have tenure during good behavior and the existence of the courts. The absence of such qualification on the tenure of the lower courts in the national constitution indicated the lack of intention to incorporate this difference. Mr. Dana added that the power to remove judges was not different from the power to remove the President, i.e., only by impeachment processes as specified in the Constitution.

Despite this eloquent defense of the judiciary, the Jeffersonians prevailed, although by but a single vote in the Senate. The courts created by the 1801 Act were abolished. No judicial test of this action was made. Following this success, the Jeffersonians sought to eliminate the Federalist judges who were holding office under the original judiciary act by bringing impeachment proceedings. They were successful in the removal of Judge Pickering of New Hampshire, but this movement foundered when the impeachment of Mr. Justice Chase failed of conviction.

\section{B. Judicial Reconstruction after the Civil War}

In the Reconstruction Congress, there was an interesting forerunner of President Franklin D. Roosevelt's court-packing plan. Of the antipathy of the Radicals to the Court, nothing need be added here. One of the attacks on the Court in the House of Representatives came under the leadership of Representative Bingham. He sought to secure an addition to the Senate Judiciary bill that would "permit" voluntary retirement of judges on pension, and would provide further: ${ }^{27}$

That if any judge who shall have attained the aforesaid age shall be incompetent, by reason of disease or infirmity, to make and file such certificate, the facts of his age and incompetency may be proved by satisfactory evidence before any judge of the Supreme Court; and upon such justice filing his certificate of such facts with the President the said judge shall thereupon be excused and retired with like effect as upon his own certificate.

Sec. 6. And be it further enacted, That within six months after the filing with the President of either of the certificates mentioned in section five of this act, or if any judge of any of the courts of the United States whose age now exceeds seventy years, or who shall hereafter arrive at the age of

27 Cong. Grobe, 41st Cong., 1st Sess. 337 (1869). 
seventy years, shall for one year after the passage of this act, or after arriving at the age of seventy years, continue to hold his office without filing such certificate, it shall in either of such cases be the duty of the President to nominate and appoint, by and with the advice and consent of the Senate, an additional judge for the said court, who shall have the same power and perform the same duties and receive the same compensation as the judge then acting in such court, or who shall be retired and excused from so acting, and shall, in connection with or in the absence of his senior associate, hold the courts prescribed by law for said senior or retired judge; and upon the decease of said senior, associate, or retired judge, or upon his ceasing for any cause to hold said office, the said additional judge appointed under the provisions of this act shall be and become the judge of such court.

On the constitutional issue, Bingham asserted: ${ }^{28}$

... I think I am justified in saying that the committee are of the opinion that it is not competent for the Congress of the United States under the Constitution to pass any law requiring a judge of the United States to resign. . . .

Mr. Speaker, there is another provision of the amendment which may become very important, the provision which provides for retiring incompetent judges and supplying their places. Suppose a judge upon your Supreme bench is struck by paralysis. He is unable to tender his resignation or to take any action in the premises. How can you supply his place except by some such provision as this, which provides for evidence being taken and for the appointment of a judge to take his place as an acting member of the court? It must occur to members of the House that there is no room for the impeachment of a United States judge on account of the visitation of God. His commission runs for life, or during good behavior; and he cannot be removed by reason of having been overtaken by disease, and thereby rendered incapable of taking his place upon the bench. ...

When Bingham was challenged on the constitutional question, a rather unenlightening dialogue followed between Bingham and Lawrence. $^{29} \mathrm{Mr}$. Jenckes, like Bingham, had little difficulty with the constitutional issue. And like Bingham, he conceded: ${ }^{30}$

We cannot, under the Constitution, compel the judges to

$28 I d$.

29 Id. at 338.

30 Id. at 340 . 
resign when they are seventy years of age and accept a pension. The law gives them the office for life or during good behavior. We cannot pass a law excluding them from the court after a certain age and allowing them to draw their present salary, or five times their present salary, if you please. They are created judges by the Constitution, and they hold their offices by a title greater than that which we can create, and their salary by a firmer tenure than that which any law can give. ...

Mr. Kerr, however, saw the problem differently: ${ }^{31}$

But, Mr. Speaker, it is proposed by this bill to retire by congressional legislation certain judges after they shall have passed the age of seventy years. The honorable gentleman from Ohio, [Mr. Bingham,] my colleague on the committee, will doubtless say that such is not the precise proposition contained in this bill. But I insist that the logical effect, the legal effect, the practical effect, of this proposition will be to retire those judges, willing or unwilling. The bill provides that the Supreme Court shall consist of nine judges; and then it is declared that whenever a judge shall have attained the age of seventy years and shall have rendered service for ten years in any judicial department of the Federal Government he may retire from active service and receive a pension equal to his salary....

The court is to consist primarily of nine judges. The gentleman from Ohio undertakes to correct me by saying that it shall ultimately consist of nine judges, together with the retired judges. The retired judges and the judges who shall be appointed to take their places are theoretically to perform precisely the same duties and to have precisely the same jurisdiction. If one holds a circuit court anywhere in the country, the other in theory of law is supposed to sit with him. If the new judge takes his seat upon the bench, the old judge may do the same. If it is competent for Congress to do thus by indirection what it cannot do directly, if it is competent for Congress to enact such a provision as this, then it is equally competent for Congress to say that after a judge shall have attained the age of sixty years or fifty years or forty years, he may in like manner be retired or superseded or may be aided by the appointment of another judge who shall sit with him, dividing with him his jurisdictiondividing with him every one of the functions of his office until, if this process be continued, the court, so far as this

31 Id. at 341-2. 
new organization is concerned, will become a mockery of a judicial tribunal.

The man who is thus superseded by the appointment of another judge is practically retired from office, and he, if not we, will so understand it. $\mathrm{He}$ and the country will understand when his successor is thus appointed by the President and confirmed by the Senate that he himself is notified that his services are no longer needed on the bench ....

It seems to me that this provision will introduce into our judicial system and into the control of Congress over it a most dangerous principle of interference, one that will go to the very fundamental idea upon which that court was organized, upon which its great service as a coordinate department of the Government must always rest. It will go directly, most logically and most dangerously, to disturb the independence of that department of the Government, and to place it, as well as all others, under the power of the legislative department, and I submit that it was that very fear, an apprehension of that very danger, a prescience of what is this day being done, that led the framers of our Constitution to incorporate the provision organizing that court precisely as it is. In this opinion I am not unsustained by the history of this provision in our Constitution. During its consideration in the Convention there was a proposition made concerning which I will read from the Commentaries of Justice Story, section sixteen hundred and nineteen:

"A proposition of a more imposing nature was to authorize a removal of the judges for inability to discharge the duties of their office. But all considerate persons will readily perceive that such a provision would either not be practiced upon or would be more liable to abuse than calculated to answer any good purpose. The mensuration of the faculties of the mind has no place in the catalogue of any known art or science. An attempt to fix the boundary between the region of ability and inability would much oftener give rise to personal or party attachments and hostilities than advance the interest of justice or the public welfare, and instances of absolute imbecility would be too rare to justify the introduction of so dangerous a provision." ...

For the very highest of reasons the constitutional Convention refused to confer upon the legislative department of the Government any right at all under any circumstances to sit in judgment upon the ability or inability of the judges of the Supreme Court. It is not permitted to Congress at all to say what shall be the exact measure of ability for a judge of that court, or what shall constitute disability for the dis- 
charge of its duties, or what age in life or service shall limit the judicial capacity. If it were, with what dangers would we be instantly surrounded! If Congress could declare that at the age of seventy years a man was incompetent to perform judicial service in that court, could not Congress, its own discretion being its supreme law, declare that a man at the age of sixty should be held thereafter to be incompetent for the discharge of such duties, or that at forty, or even at thirtyfive, he should be held to be incompetent? Whenever you leave the power at all to the legislative department you make the discretion of that body its rule of action, unless you prescribe qualifications and limitations upon that power, which it would be very difficult indeed to do. ...

The issue was fought, not in Kerr's realistic terms, but on the issue whether Congress could provide annuities for superannuated judges. Thus, Mr. Butler spoke to the constitutional issues on the assumption that all that was involved was voluntary retirement: ${ }^{32}$

What is the exact thing. we propose? That these men shall remain as judges because we cannot under the Constitution prevent that, but that they may be retired from active duty if they choose. Is there anything against the Constitution in that? My friend says we are doing that indirectly which we cannot do directly. No, sir; let me correct his phrase, with due consideration. We are allowing them to do that for themselves which we cannot do to them .... Is there anything in the Constitution which prevents that? Does it militate against the dicta of Hamilton upon this question? Hamilton feared-and it was the fear of men of his cast of thought in that day-lest there should be an attempt to remove judges by the Legislature and to overrule the judiciary, for he looked upon, and all the men of that day who thought with him looked upon the judiciary as the great arbiter between the other branches of the Government, the great protector of the rights of the people; and it was thought necessary, even at the risk of all the inconvenience that I have been speaking of, to make the judges independent of every power beyond the very power of removal. In that they but followed the great reform which had not very long before that taken place in England, by which the judges were made independent of the will of the king and held their offices during good behavior.

But, mark the difference of circumstances. We were then but just starting as a nation. John Marshall and the justices 
of that day were young men. Our fathers saw no evil or trouble arising from old age or incompetency of the judges. They were dealing with a small people. Sir, I agree it is necessary to have an independent judiciary, but it is equally necessary to have an effective judiciary. . . . And I think there is no man in the country who will not say that it is the best way for us to allow the men who from age and infirmity cannot carry on judicial work to remove themselves, and to give them this poor privilege of retiring from active service on the bench with a support for their declining years. ...

Although the Bingham amendments passed the House, the bill that was ultimately approved provided only for voluntary retirement and omitted the court-packing provisions. Reading these debates, one wonders why it took so long for Franklin Roosevelt to come up with his version of court-packing. ${ }^{33}$ Certainly Bingham had anticipated the Roosevelt plan.

\section{G. The Abolition of the Commerce Court}

The next set of congressional debates to which I refer centered, as did the 1802 contest, on the power of Congress to abolish judicial posts along with the abolition of a federal court, this time the Commerce Court of the United States. Once again political feelings ran high over the issue. The court was established in 1910, after bitter debate, to centralize review of the Interstate Commerce Commission in a single court. That the court was intended to serve and did serve as a tight rein on the Commission is clear from its antecedents and its judgments. By 1911, the court was already on its death bed.

In the background of the debates over the Commerce Court was the populist demand for a power of recall over the members of the judiciary and its opinions, led by former President Theodore Roosevelt and desperately fought by President Taft. The temper of the times may be derived from a series of Senate Documents, all of which are concerned, in whole or part, with the need to control the judiciary. ${ }^{34}$ The presence of this conflict is reflected throughout the debates. Senator Bailey's remarks are not untypical: ${ }^{35}$

But, Mr. President, if there were no other reasons I could not vote for this proposition, because it is a sort of legislative

\footnotetext{
33 See Leuchtenburg, The Origin of Franklin D. Roosevelt's "Court-packing" Plan, 1966 SUP. Cr. REv. 347.

84 See, e.g., S. Doc. Nos. 292, 302, 348, 406, 408, 451, 452, 472, 473, 892, 941, 62d Cong., 2d Sess. (1912); S. Doc. Nos. 1075, 1106, 1108, 62d Cong., 3d Sess. (1913).

3848 Cong. REc. 7843 (1912).
} 
recall of this court. That is precisely what it is, and that is precisely what it is intended to be. Some Senators, and others who have not taken the trouble to examine these decisions, are not satisfied with them, and they proceed to recall the court. If, when the court does not please the Senate, we can repeal the law which created it, we shall have precious little right to complain of those gospelers of riot and disorder who now are proposing not only to recall the courts, but to overrule the decisions of courts by plebiscite. We shall make the proposition of an ex-President eminently respectable and conservative if we go to the extent of repealing the law which created this court, because, forsooth, we do not happen to like some of its decisions.

Senator Bailey also had some interesting remarks to make about the scope of "good behavior": 36

I do not agree that a judge holds his office for life. He holds it merely during his good behavior. I have never believed that in order to remove a judge it is necessary to prove against him the same things it would be necessary to prove against an officer holding for a fixed term, who can not be impeached except for high crimes or misdemeanors.

What language of the Constitution he was relying on for this distinction is not revealed.

The House bill did not propose to abolish the judgeships along with the court. The judges of the Commerce Court had been appointed as "additional circuit judges" to sit for a period of five years on the Commerce Court but to serve by assignment on the circuit courts. At the end of five years different judges from other federal courts were to be assigned to replace these judges on the Commerce Court while these judges continued their duties on the circuit courts.

It was Senator Overman who proposed the elimination of the judgeships as well as the court. ${ }^{37}$ Thus was revived the debate of 1802, with little more contribution made to the arguments of that time, but with a few sidelights thrown on the issues more immediately relevant to the Tydings Committee's inquiries.

There is a lengthy exegesis on the question by Senator (later Mr. Justice) Sutherland. The Senate was sharply divided on the question whether existing judicial offices could be abolished thus ending the tenure of the incumbents. The 1802 precedent being thrown in his face, Sutherland quoted extensively from Story and St. George Tucker 
and their opinions that the 1802 action by Congress was unconstitutional. ${ }^{38}$ Backed to the wall by the argument that Congress had power to remove all the jurisdiction of all federal courts, except for the original jurisdiction conferred on the Supreme Court by the Constitution, Sutherland at one point agreed that the judges would have to be kept "in office" although they had no functions to perform, but ultimately fell back to Story's position that all of the jurisdiction provided in article III had to be conferred on some federal court. ${ }^{39}$

Senator Cummins, himself no mean constitutional lawyer, returned to the question of the meaning of "good behavior" and secured Sutherland's agreement in a proposal of more interest to the issues now under consideration. But he aroused the opposition of Senator Lodge: ${ }^{40}$

It would be most interesting and instructive if we were to enter for a little while, and I do intend to do it, upon the consideration of the term "good behavior"; there is a prevalent notion throughout the country that judges of the Federal courts are appointed for life. That is not true. They are appointed during good behavior. I recognize that I am not now speaking directly to the point at issue, but we so often hear the expression that Federal judges are appointed for life that I want to give some publicity to the real language of the Constitution, which is "during good behavior." I am not one of the persons who believes that the determination of what is good behavior can be had only in an impeachment trial. My friend from Utah says that unless a Federal judge is removed from his office by the process of impeachment for high crimes and misdemeanors he must remain there during his natural life. I can not agree to that statement. I do not intend to pause to even discuss what procedure could be established by Congress in order to determine what good behavior is and what it is not; but I believe that there is misbehavior on the part of a judge for which he can be removed from office that does not arise to the dignity or the severity of either a crime or a misdemeanor. . . .

Mr. Sutherland. Either I did not express myself as I intended to do so or the Senator from Iowa did not quite understand me. I did not mean to say that a judge could hold his office until he had been impeached. ... I am not at all certain but that there may be such behavior upon the part of a judge

38 Id. at 7995-6.

39 Id. at 7998 .

$40 \mathrm{Id}$. at $7999-8000$. 
short of an impeachable offense that would enable us to get rid of him. I did not mean to antagonize that position.

Mr. Cummins. I am very glad indeed that I misunderstood the Senator from Utah, because in these days when clouds are rolling around the judiciary, when various remedies are proposed for their recall, I think it is well to remember that we have somewhere, somehow, the power to determine the good behavior of the judges of the United States, and that therefore we do not need, at this time at any rate, those severer changes that are suggested in the recall by a popular vote.

I think that Congress has the power to provide for the removal of judges of the United States whenever they violate the rule which is established in the Constitution, namely, the rule of good behavior; and that means that these judges must obey, and as I am very glad to say that they generally have obeyed, the fundamental principles of propriety and of ethics.

The Senate voted to abolish the offices along with the court, but in conference, the House prevailed and the judgeships were retained.41 But this wasn't enough to save the bill from presidential veto, with language by President Taft reminiscent of the manner in which Senator Bailey started the debate in the Senate: ${ }^{42}$

... I am utterly opposed to the abolition of a court because its decisions may not always meet the approval of a majority in the Legislature. It is introducing a recall of the judiciary, which, in its way, is quite as objectionable as the ordinary popular method proposed. ...

Congress could not override the veto. ${ }^{43}$ But this was not the end of the matter.

During the third session of the 62nd Congress, the Senate found Judge Archibald of the Commerce Court guilty of the impeachment charges brought against him. ${ }^{44}$ For our purposes the most interesting materials consisted of a separate opinion by Senators Elihu Root and Henry Cabot Lodge indicating a diametrically opposed view of the concept of "good behavior" to that agreed upon by Senators Cummins and Sutherland above: ${ }^{45}$

OPINIONS OF SENATOR ROOT AND SENATOR LODGE

In the impeachment of Robert W. Archibald, January 13, 1913: I have voted that the respondent is guilty under articles

41 Id. at $800 \mathrm{I} ; 10057$.

$42 \mathrm{Id}$. at 11027.

43 Id. at $11034-5$.

4449 CoNG. REc. 1448 (1913).

$45 I d$. 
$1,2,3,5,6$, and 13 , because I find that he used the power and influence of his office as judge of the Court of Commerce to secure favors of money value for himself and his friends from railroad companies, some of which were litigants in his court and all of which were under the regulation of the Interstate Commerce Commission, subject to the review of the Court of Commerce.

I consider this course of conduct, and each instance of it, to be a high crime and misdemeanor.

I have voted "not guilty" upon the other articles, because while most of them involve improper conduct, I do not consider that the acts proved are high crimes and misdemeanors. ...

Elihu Root.

I concur in the foregoing, except as to article 4, upon which I voted the respondent guilty.

H. G. Lodge.

By the next session of Congress, Wilson had succeeded to the Presidency. The Commerce Court was doomed. But the question remained whether the judges were to be deprived of their tenure. This time the House demanded the elimination of the judges, ${ }^{46}$ but the Senate proved recalcitrant. The debate on the issue took place on the Senate floor. It was essentially a reprise of the arguments already examined and concerned only the issue of the power of the legislature to abolish judicial posts and thereby terminate the tenure of the holders thereof. Senators Borah and Walsh carried the burden of demonstrating constitutional doubts about the proposed abolition of the judgeships and Senators Bacon and Smith of Georgia were the advocates in defense of the proposition. ${ }^{47}$ The Senate version, preserving the judgeships, ultimately prevailed, so that the precedent of 1802 was not repeated.

\section{Hatton Sumners' Judicial Good Behavior Bill}

The last of my expeditions into extensive congressional debates is concerned with the proposal to provide an alternative system to that of impeachment for removal of judges. These proceedings in the 75th and 76th Congresses were not unrelated to the general problem that gave rise to the Roosevelt court-packing plan. Again, then, we have a situation in which strong political feelings against the judiciary are not irrelevant to the debate.

House Resolution No. 227 to bring this issue before the Commit-

4650 Cong. Rec. 4543 (1913).

17 Id. at $5409-18 ; 5426-9$. 
tee of the whole House was called up by Representative Smith in the first session of the 75th Congress: ${ }^{48}$

Mr. Smith. ... As you know, our customary way for the trial of Federal judges is through impeachment. I think we have all, over a period of years, come to feel that the only way to get rid of a Federal judge is through impeachment. Under the Sumners bill a method is provided which will relieve the Senate of the burden of the trial of impeachment cases of the inferior judges of the Federal courts. The bill only applies to district judges of Federal courts. [Later versions expanded the applicability to other Federal courts but not the Supreme Court.]

First, I will call your attention to the constitutional provision, which provides that Federal judges shall hold office not for life but during good behavior. We have rather come to assume that they hold office for life. They do not. They hold office, under the Constitution, only during good behavior. The purpose of this bill is to set up a court to judicially try the question of the good behavior of a Federal judge against whom impeachment charges have been preferred. Under the procedure set up in this bill we would proceed just exactly as we do today up to the point where an impeachment is voted by the House of Representatives. In other words, impeachment charges would be filed against a district judge. They would go to the Committee on the Judiciary, and that committee would consider the matter thoroughly and investigate it, and it would come into the House and be debated, and we would vote upon an impeachment resolution just as we have always done. After the House has voted the impeachment resolution, then under this bill the procedure changes. Under this bill a court is set up, consisting of three judges of the circuit courts of appeals, to be selected by the Supreme Court of the United States. Those judges would then proceed to try the question of the good behavior of the judge whose good behavior has been questioned, and if upon trial of that case they determine that his behavior was other than good behavior, he would then be removed from office; but no other penalty would attach.

There will be an amendment offered by the committee which will provide in case of those trials that after trial by the court in the first instance either side shall have the right of appeal to the Supreme Court of the United States. ... Whenever there is an impeachment trial it is necessary to consume the time of the entire Senate of the United States some-

4881 CoNG. REc. 6157-8 (1937). 
times for a period of weeks on the trial of a question of whether a minor Federal judge shall continue to hold his office. . . Necessarily, with the manifold duties of Members of the Senate, that is an unsatisfactory trial. ...

This bill will protect the judges in every way, because it will give them as fair and impartial a tribunal as they now have, but one which will give its undivided attention to the trial of the issue. There will be no danger that a judge may be hauled up and tried for some trivial charge, because, first, it has to come under the present procedure, and there has to be an impeachment resolution offered on the floor. It must be considered by the Committee on the Judiciary and voted out, and then it must come back to the floor of this House and be debated before an impeachment resolution is voted. Only after that impeachment is voted can his conduct be tried. ...

Representative Sabath also spoke for the bill, ${ }^{49}$ but its chief proponent was its sponsor, the chairman of the House Judiciary Committee, Representative Sumners, who undertook to explain and defend it at length: ${ }^{50}$

This bill does not at all rest upon the provision of the Constitution dealing with impeachment. The thing which we are attempting to do here has absolutely no relationship to the impeachment power. The last part of article II deals with impeachment. ...

... [It $]$ is the good behavior clause which this bill seeks to have recognized; that is, "good behavior" as a justiciable issue. When we read that provision we find that judges are not appointed for life, but are appointed during good behavior. It is a condition attached to their right to hold office. When they violate that condition they not only bring disgrace upon the giver of their commission but they forfeit their right to hold office. If we get that in our mind, we then have the second proposition.

If the Senate cannot make vital the "good behavior" provision in the judicial tenure clause, and clearly it cannot do it, what agency of government can do it? The historical background precludes any notion that the President can effectuate those words, because those words went into the framework of the English constitution, from which we appropriated them, in order to prevent the Executive from having

49 Id. at $6161-2$.

$50 I d$. at 6163-6. 
anything to do with it. So, by the process of elimination we come to a court as the only agency of government that can keep those words from being dead words in the Constitution. I think everybody must agree with that. . . .

Mr. Mott. I do not agree and I want to tell the gentleman my interpretation just in a word and ask him what is the matter with it. It has always been my opinion that the reason why "good behavior" was inserted in that clause of the Constitution was so that judges appointed for life could be impeached. In other words, if this provided that judges should hold their terms for life, then the language would be repugnant to section 4 of article II, and it is doubtful if you could impeach, and I think it is for that reason that section 1 specified the term during good behavior instead of life. What is wrong with that?

Mr. Sumners of Texas. I say with all respect that is the expression of an immature judgment which is found in ninetenths of American lawyers. I went through the same process or rather from the same starting point. We all start with the notion that we can only remove a judge by impeachment. This is what is wrong with it. All civil officers are subject to removal by impeachment. The length of the terms of office has nothing to do with it. Whether for 4 years, during good behavior, or for life, it is all the same. If they commit "high crimes and misdemeanors" and so forth they bring themselves within the powers of the Senate to remove by impeachment.

"Good behavior" by its nature is a justiciable issue. By its use it is made a condition in the right of every judge to hold office. It is a triable issue. There is no court to try it. This bill provides the court. If there is no court there is no agency to make effective that important condition in this particular section of the Constitution. ... .

Unquestionably it is a fact as everybody will agree that we took the provision of our Constitution under consideration from the English Constitution. Everybody knows that. I have in my hand a recognized authority as a commentator on the English Constitution, Todd. He says that "good behavior" in the English Constitution has always been recognized as a justiciable issue, triable in their courts by scire facias, a proceeding similar to our quo warranto. . . .

It was recognized in England, when we brought this provision into our Constitution, that there were four methods of getting rid of judges: By impeachment; by joint address of the two Houses; by conviction for an offense; and by writ of scire facias, which is exactly the process that we expect to institute under this provision.... 
It is a queer thing that the notion is so deeply rooted that because we may remove a judge by impeachment we may not remove him by court action in a suit brought to enforce a clear condition attached to his right to hold office. . . .

A constitutional challenge came from Mr. Gwynne. ${ }^{51}$ But the main spokesman for the opposition was Mr. Celler: ${ }^{52}$

Mr. Chairman, from my review of the cases, the Constitution itself, the authorities, and the debates in the original Constitutional Convention, I am firmly of the conviction that we have no authority whatsoever to pass this bill. I sympathize fully with the objectives sought; I believe that the trial of an accused judge by impeachment is highly unsatisfactory; nevertheless, despite my sympathy with the objectives of the bill, I do not believe that it can be accomplished legally or constitutionally. There is no short cut. If we want to change the method of trial of judges accused, we must follow the Constitution. To do it in the way that our distinguished chairman wishes to do it would require, beyond peradventure of doubt, a constitutional amendment.

We often grow impatient with our judiciary, and especially so when they decide against us or when they in their decisions or opinions develop economic or political views differently than we would, or when we do not agree with the results generally, even though it does not affect us materially; but when sensible men viewing in retrospect what our district courts, our circuit courts, and our Supreme Court have done they will have naught but praise for our courts. . . .

I want to maintain as much independence for our judiciary as is possible, and the only way that we can maintain an independent judiciary is to make attack upon them difficult, not too easy; otherwise the judges will no longer be independent, but will truckle to this influence and that influence, to this personage and that personage, and we would, therefore, strike a decided blow at the judiciary and destroy their independence. [Applause.] Now, insofar as you make these attacks upon the judiciary easier I am against it. . . .

I may say with all due deference to the author of the bill that the best argument against its validity is its novelty. I said this in the minority report and I am going to repeat it:

It scarcely can be believed that the framers intended vesting Congress with an important power and then

$51 \mathrm{Id}$. at $6169-70$.

$52 \mathrm{Id}$. at $6170-3 ; 6187$. 
so skillfully concealed it[,] it could not be discovered save after 150 years.

.. I have before me the Federalist, volume 2, numbers 65 and 66, with contributions by Hamilton, Madison, and Jay. It covers the matter of impeachment. There is a clear indication that the framers of the Constitution wished to limit beyond any question the right to impeach and try judges, to limit the right of removal, to the Congress of the United States. Particularly we are told that efforts were made to set up a different tribunal. An effort was made to set up the Supreme Court as a tribunal to try these recreant judges. We are told by these savants that the framers in the Constitutional Convention rejected every solitary one of the proposals other than the one we find in the Constitution.

Now, that is the best argument in the world. They rejected every single proposal, except that the House shall impeach and the Senate shall try the cause. The House shall be the sole entity to bring impeachment charges. We are told in article I, section 2:

And the House of Representatives shall have the sole power of impeachment.

We are told in article I, section 3:

The Senate shall have the sole power to try all impeachments.

The use of the word "sole" in those two particulars undoubtedly is most significant, particularly in the light of the history of the Constitutional Convention, which we are told rejected all alternatives except the one we have followed for 150 years. Therefore, I cannot lay too great emphasis on the use of the word "sole" in two instances. To my mind the conclusion is inescapable that the only way you can try these judges is by the method that the Constitution allows us to use, and I do not care what you call the trial, whether impeachment, ouster, removal, or by any other name. . . .

The gentleman from Alabama [Mr. Hobbs], my very dear friend who sits next to me, has issued a challenge to me, and has asked me to show by reference to the Constitution or by reference to the debates in the Constitutional Convention, that there was any argument on any basis for this additional method of removal. I refer the gentleman to the debate in the Constitutional Convention held as of Monday, August 27, 1787, which clearly indicates, to my mind, that the framers of the Constitution intended only one method of ouster of judges, namely, impeachment. ...

Reed of Illinois and Tolan of California, Hobbs of Alabama, and Robinson of Kentucky all spoke at length in favor of the constitution- 
ality of the bill. ${ }^{53}$ Hancock of New York, Michener of Michigan, and Sauthoss of Wisconsin were all vigorous opponents. ${ }^{54}$

The bill passed the House of Representatives by a vote of 221 to 125 . (In the majority were Congressmen Lyndon B. Johnson and Fred M. Vinson; among the dissenters was Congressman Everett M. Dirksen.) It was referred to the Senate Judiciary Committee ${ }^{55}$ and appears to have died there.

The issue was revived in the first session of the 76th Congress by Congressman Sumners. This time courts of appeals judges were also placed under the Damoclean sword. ${ }^{56}$ But not until the third session did debate again occur. This time Hobbs led off the fight with an extensive constitutional defense of the proposal..$^{57}$ Sumners again waxed long and eloquent on behalf of his bill. ${ }^{58} \mathrm{Mr}$. Michener organized the attack on constitutional grounds and was supported by Lewis of Ohio and Rees of Kansas. ${ }^{59}$ Mr. Guyer of Kansas, Mr. Hancock of New York, and others argued at length in defense of this bill.60 The battle was long, but the bill was defeated, 236 Nays to 104 Yeas.

The war, however, was not quite over. A similar bill was introduced in the 77th Congress by Sumners and this time he squeezed it past the House by a vote of 124 to $122 .{ }^{.61}$ Nothing more came of this bill or of similar bills offered by Sumners in the House in the 78th and 79th Congresses. But the Senate Judiciary Committee did hold hearings on the Sumners bill for the 77th Congress and evoked testimony from Mr. Justice Jackson in favor of the principle of the bill and the need therefor if not in favor of its constitutionality. ${ }^{62}$ This ended, temporarily at least, the movement for judicial removal by means other than impeachment.

\section{EXEcutive OpINIONS}

The views of the executive branch of the Government on this subject are more elusive. But the isolated examples that $I$ have uncovered

53 Id. at $6173-5 ; 6176-9 ; 6181-4$.

$54 I d$. at $6166-7 ; 6179-81 ; 6181$.

$65 \mathrm{Id}$. at 6207.

58 See 84 Cong. Rec. 25, 4638, 5096 (1939); H.R. REP. No. 537, 76th Cong., 1st Sess. (1939).

5786 ConG. Rec. $4197-4200$ (1940).

$58 \mathrm{Id}$. at $4202-6$.

$69 \mathrm{Id}$. at $4200-1 ; 4201 ; 4202$.

$60 \mathrm{Yd}$. at 4206-12.

61 87 CoNG. REc. 8168 (1941).

62 See note 10 supra. For further, if repetitive, exegesis on the constitutional question, see H.R. REP. No. 814, 75th Cong., 1st Sess. (1937); H.R. REP. No. 537, 76th Cong., Ist Sess. (1939). 
indicate an understanding little different from the views of the other branches.

Thus, Thomas Jefferson, prior to his Presidency, thought that appointments with life tenure was the appropriate term for judicial office: "The judges ... should not be dependent upon any man or body of men. To these ends they should hold their estates for life in their offices, or in other words, their commissions should be during good behavior." 63 That he had lost the taste for this protection of the independence of the judiciary by the time of his Presidency is common knowledge. It was he who sponsored the successful attack on the 1801 Judiciary Act. It was he who sponsored the impeachment attacks on the federal judiciary. It was he, when he found that impeachment was not a successful method for removal of Federalists from the bench, who resorted to proposed constitutional change of the life tenure and good behavior provisions.

Dean Leonard Levy describes Jefferson's reactions to his political frustrations: ${ }^{64}$

Since impeachment was a "farce," he wrote, an amendment was needed to rebuke the judiciary for extending "immunity to that class of offenders which endeavors to overturn the Constitution, and are themselves protected in it by the Constitution ... If their protection of Burr produces this amendment, it will do more good than his condemnation would have done."

... After Burr's acquittal Jefferson declared once again that the result was "equivalent to a proclamation of impunity to every traitorous combination which may be formed to destroy the Union," but an amendment to the Constitution would make the judiciary dependent on the "nation."

... The amendment recommended by Jefferson throughout 1807 had originally been proposed by John Randolph, first in 1805 and again in 1806. It made federal judges removable by the President on the joint address of both houses of Congress. A few days after Jefferson's Seventh Annual Address, Senator Edward Tiffin of Ohio offered the same amendments, with the additional provision that the judges' tenure be limited to a specified number of years. The proposed amendment however was not reported out of committee. Jefferson's goal of checking the judiciary failed. His advocacy in 1789 of an independent judiciary as a means of enforcing civil liberties against the government better comports with the image of him as the apostle of freedom. ...

63 Quoted in E. Haynes, Selection and Tenure of Judges 93 (1944).

64 L. LEVY, JEFFERSON AND CIVIL LIBERTIES 79-81 (1963). 
Perhaps the most interesting aspect of the Jeffersonian position is that he did think it necessary to resort to constitutional, not merely legislative, changes to effect his objectives.

In 1868, President Johnson, who showed more prescience than he has been given credit for, proposed several amendments to the Constitution, again including one that would limit the tenure of the judicial office: ${ }^{65}$

It is strongly impressed on my mind that the tenure of office by the judiciary of the United States during good behavior for life is incompatible with the spirit of republican government, and in this opinion I am surely sustained by the evidence of popular judgment upon this subject in the different States of the Union.

I therefore deem it my duty to recommend an amendment to the Constitution by which the terms of the judicial officers would be limited to a period of years, and I herewith present it in the hope that Congress will submit it to the people for their decision. ...

His other proposals for constitutional amendment included direct election of the President and Vice-President, provision for succession to the office of the President, and direct election of Senators. Two of his recommendations for constitutional change have been effected, one-relating to the electoral college-may be on its way to effectuation, and the fourth is again the subject of serious consideration by Congress.

At the time of the Commerce Court debates referred to at length above, the courts of the country were subject to severe attack, with ex-President Theodore Roosevelt the leader of the battle for judicial recall while the defenders of the judiciary were led by President Taft. Taft, like Jefferson, was of different minds at different times on the subject of retirement of the judiciary upon reaching a specified age. While President he favored such a retirement plan; after the became Chief Justice he was opposed to it.

Attorney General Cummings relied on Taft's position as the basis for a suggested constitutional amendment in 1938. His belief in the need for constitutional amendment to effect an age limit on the office is emphasized by the fact that he suggested a legislative remedy for voluntary retirement with compensation: ${ }^{86}$

656 Messages and Papers of the Presidents 643, 691 (Richardson ed. 1900). 681938 ATT'Y GEN. ANN. ReP. 5. 


\section{COMPULSORY RETIREMENT OF FEDERAL JUDGES}

Former President Taft asserted that the failure of the Constitution to provide for the compulsory retirement of Federal judges at the age of 70 was a defect which should be remedied. This view is held by a large number of eminent jurists and lawyers. It is also, I believe, in accord with the majority opinion of our people. So many disadvantages have resulted from the existing system that I do not pause to enumerate them. Of course, provision should be made for full pay upon such retirement. I, therefore, recommend the adoption of a constitutional amendment to accomplish the desired result. By its express terms such an amendment should be made applicable only to those appointed after its adoption.

In addition, some statutory provision (presumably on a pro rata basis) should be made for voluntary retirement of Federal judges who have become disabled prior to reaching the age of 70. Not infrequently instances of this kind have occurred. Such a situation is unfair to the incapacitated judge and detrimental to the public interest.

The limitations on legislative power to control the judiciary were also revealed in the choice of remedies made by President Franklin D. Roosevelt in his famous-or infamous-court-packing plan. It was thought that the plan derived from Attorney General McReynolds' report for 1913. McReynolds' recommendation had stated: ${ }^{\mathbf{6 7}}$

Judges of the United States Courts, at the age of 70, after having served 10 years, may retire upon full pay. In the past, many judges have availed themselves of this privilege. Some, however, have remained upon the bench long beyond the time when they were capable of adequately discharging their duties, and in consequence the administration of justice has suffered. ... I suggest an act providing that when any judge of a Federal court below the Supreme Court fails to avail himself of the privilege of retiring now granted by law, that the President be required, with the advice and consent of the Senate, to appoint another judge, who would preside over the affairs of the court and have precedence over the older one. This will insure at all times the presence of a judge sufficiently active to discharge promptly and adequately the duties of the court.

As I have already pointed out, the Reconstruction Congress had anticipated McReynolds. There is some irony in the fact that this propo-

671913 ATT'y GEN. ANN. REP. 5. 
sal, so roundly defeated in Congress when it related to the Supreme Court, was later revived with regard to lower court judges in the Attorney General's Reports for 1956 and 1958 and was enacted into law by Congress and is now to be found in 28 U.S.C. $\S 372(\mathrm{~b})$.

My final reference to the position taken by the executive on the questions before the Tydings Committee is Attorney General Biddle's support of the constitutionality of the Sumners bills that were treated above. ${ }^{68}$

\section{Conclusion}

Largely on the basis of the materials set out or referred to herein, I am quite convinced that it would be unconstitutional for the Congress to attempt, by legislation, to establish a fixed term of office for judges of the federal constitutional courts. I am also of the opinion that the greater weight of authority lies on the side of lack of power to establish a mode of trial other than by impeachment for the removal of federal judges. And, for me, it follows that legislative action spelling out the content of "good behavior" for such trials would also be invalid, for the content of those words are either (1) to be derived from the definition of high crimes and misdemeanors, or (2) to be left to the discretion of the Senate when sitting as a court of impeachment. But on these latter questions, no one should claim certainty. And it must be conceded that a determination by Congress that legislation on one or both of these latter points is constitutional should weigh heavily in favor of its validity if the issue comes to judicial scrutiny. My understanding about the need for constitutional amendment to effect a change in life tenure is buttressed by the repeated introduction in both Houses of Congress of amendments to that end. ${ }^{69}$

Especially in the absence of a weighty factual demonstration of the need for legislation providing for removal of federal judges by means other than impeachment-a case that has not been made and, I think, cannot be made-I should favor treatment of the alleged problems of judicial tenure by constitutional amendment. This was the choice made for resolution of the problem of presidental succession. This is the choice being made for cure of the alleged evils of the electoral college against claims for judicial revision. This should be

68 Hearings Before a Subcomm. of the Comm. on the Judiciary of the United States Senate on H.R. 146, 77th Cong., lst Sess. 31-39 (1941).

69 The policy arguments on this issue are extensively set out in Hearings on S.J. Res. 44, H.R. J. Res. 194, and H.R. J. Res. 91, Before Subcomm. No. 4 of the House Comm. on the Judiciary, 83rd Cong., 2d Sess., ser. 11 (1954); Hearings on S.J. Res. 44 Before a Subcomm. of the Senate Comm. on the Judiciary, 83rd Cong., 2d Sess., ser. 11 (1954). 
the means for dealing with the issue of judicial removal. We have here no threat of majority imposition on the rights of minorities through constitutional amendment. We have here, instead, a proposal to effect a change in the structure of government that most people would, with some reason, regard as a fundamental revision of our constitutional system. If a case can be made for it, I can see no reason for failing to take the issue to the people.

It should be kept in mind that the provisions for securing the independence of the judiciary were not created for the benefit of the judges, but for the benefit of the judged. It is not in the keeping of the judges to surrender this independence under pressure or voluntarily to give it away. Judicial independence is held in trust for the people and only they should determine whether they would like to exchange some judicial independence for more judicial efficiency. 